\title{
Biological Safety Evaluation of 99mtc-Dtpa-Ketoconazole for Diagnosis of Fungal Infection
}

\author{
Maula Eka Sriyani, Hendris Wongso, Eva Maria Widyasari, Rizky Juwita Sugiharti, Iim \\ Halimah, Iswahyudi, Ahmad Sidik, Epy Isabela, Witri Nuraeni
}

National Nuclear Energy Agency (BATAN), Jl. Tamansari No. 71 Bandung, 40132, Indonesia

Received: 10 June 2015, Revised: 30 September 2016, Accepted: 10 April 2016

\begin{abstract}
Infectious diseases have become one of the leading cause of mortality around the world, including in the Southeast Asia. One of the microbial that cause infection is fungi. Occasionally, deep-seated fungal infection is difficult to detect using conventional diagnosis methods and therefore leads to inaccurate detection. Our previous research was conducted in order to obtain the labeled compound of 99mTc-DTPA-Ketoconazole with a high radiochemical purity

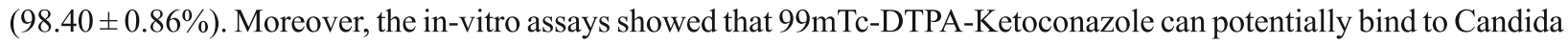
albicans. On the other hand, in clinical routine use, diagnostic kit should be safe for the patients. Consequently, this research was conducted to determine the biological safety parameters of 99mTc-DTPA-Ketoconazole on the animal study, including single dose and acute toxicity test, sterility, and apirogenicity test. The results showed that both the single dose at $34.6 \mu \mathrm{Ci}$ and dose until 149 times of the single dose did not stimulate the toxic response to the animals. In addition, the sterility data revealed that there was no microbial growth after 7 days of incubation at $37^{\circ} \mathrm{C}$ as well as fungal growth after 14 days of incubation at $25^{\circ} \mathrm{C}$. Furthermore, the apirogenicity test using rabbits revealed that there was no increase in temperature more than $0.6^{\circ} \mathrm{C}$ for each animal and not more than $1.5^{\circ} \mathrm{C}$ of total increase of temperature for all the animals. It is concluded that the $99 \mathrm{mTc}-\mathrm{DTPA}-K e t o c o n a z o l e$ is satisfy the requirements of biological safety of a radiopharmaceutical and therefore was acceptable for fungal detection in nuclear medicine.
\end{abstract}

Keywords: fungal infection; 99mTc-DTPA-Ketoconazole; biological safety evaluation; toxicity, sterility; apirogenicity.

\section{INTRODUCTION}

Infection is a process in which microbes such as bacteria, viruses, fungi, or other organisms invade the human body, attach to cells, multiply, and cause certain disease (Anonim, 2011). Recently, infectious diseases have become one of the major health problem that cause mortality worldwide. According to WHO data in 2012, about 9.5 million death was caused by infectious diseases in parts of Africa, Southeast Asia, and the Middle East region (Foxman, 2011). Infectious diseases can also reduce the level of productivity of a person. A major factor that cause infectious diseases become difficult to be cured is the difficulty to determine the presence of pathogens, especially in deep-seated infections. Specifically, one of pathogenic fungi that may generate deepseated infection is $C$. albicans which is the normal flora that usually can be found in the mucous membranes of the respiratory tract, gastrointestinal tract, and vagina. In some cases, if the amount of C.albicans is excessive, it can cause numerous diseases, such as canker sores, intestinal candidiasis, vaginal candidiasis, and systemic candidiasis (Tjay, 2007). One of the drugs of choice which is widely used to treat the fungal infections including C.albicans and some other microbes is ketoconazole. Chemically, ketoconazole is an imidazole derivative that has the mechanism of action by binding directly to the cytochrome P450 enzyme and inhibit the synthesis of ergosterol which is necessary to the formation of fungal cell membranes, thus cause lysis of the fungal membranes.

(Tjay, 2007). Based on the molecular structure of ketoconazole (Fig.1), it has a functional group that allows it to be labeled with 
a radionuclide, such as technetium- $99 \mathrm{~m}(99 \mathrm{mTc})$ leads to a promising radiopharmaceutical for detecting C.albicans. Recently, $99 \mathrm{mTc}$ is the common radionuclide used in nuclear medicine for imaging several diseases and is contributed to $80-85 \%$ of clinical applications, especially for diagnosis as $99 \mathrm{mTc}$ has some advantages such as the ideal half-life (6.0 hours) and emits pure gamma ray $(\gamma)$ with energy of $140 \mathrm{KeV}$ (Verbruggen, 2007).

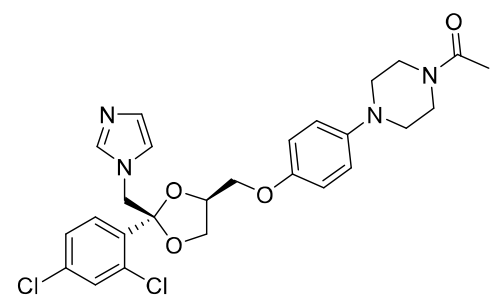

Figure 1. Chemical structure of Ketoconazole (Oh et al., 2012).

More importantly, the gamma energy of $99 \mathrm{mTc}$ does not stimulate any cell damages in human. Therefore, in clinical routine use, $99 \mathrm{mTc}$ can be administrated by direct injection even with dose over $30 \mathrm{mCi}$ without significant radiation effect to the patient. Moreover, its energy property makes it suitable for studying the organs, which is located deep in the body. In addition, a primary advantange of $99 \mathrm{mTc}$ is it can bind to a numerous of organic molecules which have an electron donor group (Zolle, 2007; Schwochau, 2000; Saha, 2010; Owunwanne, 1995). Some studies demonstrated that $99 \mathrm{mTc}$ still become a primary radiotracer in nuclear medicine, especially for imaging infectious diseases. Recently, Welling, et al. reported several radiopharmaceutical that potentially used to detect infections (Welling., 2009). In addition, several studies reported that $99 \mathrm{mTc}$ as an imaging agent for infections have used in some cases (Dass et al., 2002), for instance, by Awaludin and colleagues (Awaludin, 2011). In their review, they showed that $99 \mathrm{mTc}$ is widely used in nuclear medicine, including for imaging infectious diseases. Moreover, Motaleb (Motaleb., 2011) in 2011 revealed the potential use of $99 \mathrm{mTc}$ gatifloxacin and $99 \mathrm{mTc}-C e f e p i m e$ for imaging bacteria infections. Similarly, over the last decade, some imaging agents have developed to detect the fungal infections, such as $99 \mathrm{mTc}$-Ciprofloxacin (Nurlaila et al., 2005), 99mTc-aptamers (Roberta et al., 2015), 99mTc- Ceftriaxone (Kaul et al., 2013), and 99mTc- Danofloxacin (Moustapha, 2016). Some of these radiopharmaceuticals showed a specific detection for bacterial infection or sterile inflammation, however (Moustapha, 2016) less specific for detecting fungal infections. More recently, in 2014 99mTc-caspofungin was also developed for the diagnosis of fungal infections (Yazdani et al., 2014).

Studies suggested that Ketoconazole will interact with fungi in the area of infection, while radionuclide $99 \mathrm{mTc}$ will emit $\gamma$ radiation during the imaging process and will be directly captured by the gamma camera from outside the body. The rapid and accurate diagnosis are necessary because of the death by the infection often caused by the failure or delay in the process of diagnosis, so it leads to the ineffective treatment. The labelling techniques of $99 \mathrm{mTc}$ - DTPA-Ketoconazole (Sriyani, 2013) have been conducted by our groups and provides the high radiochemical purity. Subsequently, 99mTc- DTPA-Ketoconazole will undergo a quality control. This procedure is divided into two categories: the determination of physicochemical properties and biological safety determination which includes the toxicity (Halimah et al., 2009), sterility, and apirogenity (Saha, 2010). Physicochemical properties determination (Sriyani, 2013) has been conducted in the previous studies, as well as biological study such as microbial uptake (Sriyani et al., 2015). Therefore, the purpose of this study was to determine the biological safety aspect of 99mTc-DTPA-Ketoconazole to fulfil 
the safety aspect requirement of a diagnostic kit for patients.

\section{MATERIALS AND METHOD Materials}

Ketoconazole (obtained from the School of Pharmacy, ITB), Diethylene triamine Penta Acetate (DTPA), Na99mTcO4 (ANSTO), $\mathrm{NaCl}$ $0,9 \%$ (IPHA), aquabidest sterile pro-injection (IPHA), $\mathrm{HCl}$ (E. Merck), $\mathrm{NaOH}$ (E. Merck), alcohol 70\%, nutrient agar medium (Oxoid, England), saboroud agar (Merck, Germany) and thioglycolic liquid (Merck, Germany) for the sterility test.

This study was used two types of animals which are white mice (Mus musculus) Swiss strain and rabbits. White male mice 4-5 weeks old with the weight of 30-40 grams were used for toxicity test, while the white rabbit 2-3 months old with the weight of $2-3 \mathrm{~kg}$ were used for apirogenicity test. The use of both types of animals based on the methods as outlined in the Indonesian Pharmacopoeia Edition V as well as the general procedure for radiopharmaceutical quality controls. The use of animals in this study has been approved by animal ethics committee (KEPPHP) BATAN No. 001 / KEPPHPBATAN / IV / 2014.

The equipments used in this study were syringe $1 \mathrm{~mL}$, thermocouple, rabbit restrainer, analytical balances (Mettler Toledo), laminar airflow (BBL Biological Cabinet), incubator (Memmert), Single Channel Analyzer (Ortec) and Dose Calibrator (Victoreen), autoclave (Hirayama), vortex mixer, test tubes, petri dishes, syringe filters, test tube rack, micro pipette (Eppendorf) and needle ose.

\section{Methods}

\section{Toxicity test}

A single dose toxicity and acute toxicity test were carried out in this study. These procedure are performed based on the guidance from the Indonesian Pharmacopoeia. In single dose toxicity test, $34.6 \mu \mathrm{Ci}$ of $99 \mathrm{mTc}$-DTPAKetoconazole was injected intravenously per mouse ( 5 mice in total). For acute toxicity test, the dose of $99 \mathrm{mTc}$-DTPA-Ketoconazole was increased up to 150 times of the single dose. The results are acceptable if there is no animals become sick or die at the end of 48 hours after injection, or no more than an animal shows any unusual symptoms or behaviour. If one or more animals die or if more than one animal show abnormal toxicity symptoms or behaviour, the experiment should be repeated using at least 10 mice. If the animals do not demonstrate any symptoms of abnormality at the end of 48 hours after injection, the observation was continued for up to 7 days, and then continued until 14 days (Kementerian Kesehatan Republik Indonesia, 2014).

\section{Sterility test}

Direct inoculation test method used in this study. The test was conducted on the clean laminar airflow that has been sterilized prior to use. DTPA-Ketononazole kit was prepared by adding $2 \mathrm{~mL}$ of sterile physiological saline into the DTPA-Ketononazole kit and then shaken until homogeneous. Three types of media were used in this test, which are liquid thioglycolic, saburoud agar, and nutrient agar. Liquid thioglycolic in the test tubes was opened near the flame of the bunsen, $20 \mathrm{~mL}$ of the kit was added, then closed with cotton lid. To the nutrient agar and Saboroud agar in each petri dish was poured $1 \mathrm{~mL}$ of DTPA-Ketononazole. Each test was performed a total of three times (triplo). As controls, the test tube contains thioglycolic liquid, a petri dish containing nutrient agar, and a petri dish containing saboroud were opened and placed in a laminar airflow during the test. Subsequently, liquid 
thioglycolics and nutrient agars containing samples were incubated in an incubator at $37^{\circ} \mathrm{C}$ for 14 days, while the saboroud agars were incubated at room temperature $\left(25^{\circ} \mathrm{C}\right)$ for 14 days. Bacterial and fungal growth were observed daily for 14 days by observing the presence of contaminants (colony) of bacteria or fungi on agar medium and the change of turbidity in thioglycolic medium (Kementerian Kesehatan Republik Indonesia, 2014).

\section{Apirogenicity test}

Apirogenicity test was conducted as outlined in the Indonesian Pharmacopoeia V and general procedures radiopharmaceutical quality control (Kementerian Kesehatan Republik Indonesia, 2014; Anonymous, 2008). This test was carried out using three rabbits and was measured by the change of rabbits temperature. The temperature of each rabbit was measured by inserting a thermocouple probe that has been smeared with lubricant, into the anus of rabbits with a depth of $\pm 2 \mathrm{~cm}$ to obtain a constant temperature. The initial temperatures of rabbits were determined at 30 minutes before the injection of the radiopharmaceutical. Subsequently, 99mTc-DTPA-Ketocononazole was injected intravenously through the auricular vein in the rabbit ears. Rabbits temperature were measured again at the $0,60,120$, and 180 minutes (interval 60 minutes after injection). The highest temperature obtained starting from the 60 minute after injection until minute 180 was called the maximum temperature.

The calculation of the temperature change is determined by using equation (1) below:

$$
\mathrm{T} \text { initial }=\mathrm{T} \text { at } 30^{\prime}(1)
$$

$\mathrm{T}$ maximal response $=\mathrm{T}-\mathrm{T}$ initials $(2)$

- The temperature of the initial ( $\mathrm{T}$ initials): the temperature at 30 minutes before the injection.
- Maximum Temperature (T maximum): The highest temperature on the measurement of 3 hours after injection.

- Temperature response ( $\mathrm{T}$ response): the difference between the $\mathrm{T}$ maximum and $\mathrm{T}$ initials.

\section{RESULTS AND DISCUSSION}

Radiochemical purity is one of the important characteristics of a radiopharmaceutical. As a fundamental procedure in nuclear medicine, the radiochemical purity of a radiopharmceutical for clinical application should be $95 \%$ or higher [19]. In this study, the radiochemical purity of $99 \mathrm{mTc}$-DTPA-ketoconazole was obtained at $98.40 \pm 0.86 \%$ and therefore is acceptable as an approriate radiopharmaceutical for further biological analysis. Furthermore, the toxicity test was also conducted to determine the toxicity properties of $99 \mathrm{mTc}$-DTPAKetononazol in humans or animals. To obtain equivalent pharmacological effects of a radiopharmaceutical in every species of animal, it is necessary to determine a data regarding the use of quantitative dose [25]. Therefore, in this study, the conversion dose was calculated for every specific animal. In this case, the dose of the radiopharmaceutical for the human need to be converted to animal dose according to the body surface area comparisons (Table 1).

Table 1. The conversion of the dose based on body surface area (Juwita et al., 2007)

\begin{tabular}{|c|c|c|c|c|}
\hline & Mice & Mouse & Rabbit & Human \\
\hline Mice & 1.0 & 7.0 & 27.8 & 387.9 \\
\hline Mouse & 0.14 & 1.0 & 3.3 & 56.0 \\
\hline Rabbit & 0.04 & 0.25 & 1.0 & 14.2 \\
\hline Human & 0.0026 & 0.018 & 0.07 & 1.0 \\
\hline
\end{tabular}

Based on table 1, it can be calculated that the dose conversion factor for sub-chronic toxicity test of $99 \mathrm{mTc}-\mathrm{DTPA}-K e t o c o n a z o l e$ is 0.0026 times lower than the dose administrated 
to humans. Based on this calculation, a single Dose increased Initial condition post injection Condition of 24 hours post injection dose was administrated to each animal at $34.6 \mu \mathrm{Ci}$.

Toxicity test was conducted in a singledose toxicity for sub-chronic toxicity and acute toxicity test. In this test, three healthy white mice (M. musculus) strain Swiss was used. The observation of a single dose subchronic toxicity test such as mortality, appetite, behavior disorders, eye color, fur condition, and animal activities did not show any evidence of abnormality. Similarly, the increasing of dose until 150 times from initial dose showed negative toxicity behaviours. For detail, the acute toxicity test results are shown in Table 2. Overall, this data suggest that 99mTc-DTPAKetokonazole demonstrates non-toxic effects on animals.

Table 2. The observation of acute toxicity of $99 \mathrm{mTc}-$ DTPA-Ketoconazole

\begin{tabular}{ccc}
\hline $\begin{array}{c}\text { Dose } \\
\text { increased }\end{array}$ & $\begin{array}{c}\text { Initial condition } \\
\text { post injection }\end{array}$ & $\begin{array}{c}\text { Condition of 24 } \\
\text { hours post injection }\end{array}$ \\
\hline $\mathbf{2 . 0}$ & Normal & Normal \\
7.2 & Normal & Normal \\
17.3 & Normal & Normal \\
39.0 & Normal & Normal \\
65.5 & Normal & Normal \\
149.1 & Normal & Normal \\
\hline
\end{tabular}

In clinical application, 99mTc-DTPAKetoconazole should be administered parenterally. Therefore, this radiopharmaceutical must be sterile and not contain pyrogens. The sterility data observations can be seen in Table 3 . It can be seen that 99mTc- DTPA-Ketokonazole is sterile, as evidenced by the absence of either the growth of bacteria and fungi (fungi) after incubation up to 14 days.

The other requirement for an appropriate radiopharmaceutical in clinical use is the absence of pyrogen. Pyrogens are defined as metabolic outcomes from the living or dead microorganisms which cause specific pyretic response after the injection of a radiopharmaceutical. As the pyrogens are water-soluble, the sterilization process with steam under pressure and filtration through a syringe filter may be unuseful, although this process can eliminate the microorganisms. Pyrogenic reactions in the human body are indicated by the fever and chills symptoms soon after the injection or between 45 to 90 minutes after injection of the radiopharmaceutical. Therefore, the presence of pyrogens is not allowed in a radiopharmaceutical. In this study, we determined the presence of pyrogens using healthy rabbits. The temperature changes were observed in rabbits after injection of the radiopharmaceutical. Before the injection of the radiopharmaceutical, the temperature of rabbits were measured as the initial temperature. The body temperature measurement is carried out by a thermocouple into the rectum of rabbits at 1-2 $\mathrm{cm}$ deeps. Before used, probe should be smeared with the commercial lubricant to avoid irritation when the probe entering the anus (Hendris, 2013). Pyrogen test results are shown in Table 4.

Based on the observation, the increasing of temperature from all of the rabbits after

Table 3. Sterility test of $99 \mathrm{mTc}$-DTPA-Ketoconazole

\begin{tabular}{|c|c|c|c|c|c|c|c|c|c|}
\hline \multirow{2}{*}{ Sample } & \multirow{2}{*}{ Testing medium } & \multicolumn{8}{|c|}{ Day of observations } \\
\hline & & 0 & 2 & 4 & 6 & 8 & 10 & 12 & 14 \\
\hline \multirow{4}{*}{$\begin{array}{l}\text { 99mTc-DTPA- } \\
\text { Ketokonazol }\end{array}$} & Nutrient Agar & - & - & - & - & - & - & - & - \\
\hline & & - & - & - & - & - & - & - & - \\
\hline & Thioglicolic & - & & & & & & & \\
\hline & & - & - & - & - & - & - & - & - \\
\hline Control & & - & & & & & & & \\
\hline
\end{tabular}


Table 4. Pyrogenic test of 99mTc-DTPA-Ketokonazol

\begin{tabular}{cccccccc}
\hline \multirow{2}{*}{ No. Rabbit } & \multirow{2}{*}{ Initial temp. $\left({ }^{\circ} \mathbf{C}\right)$} & \multicolumn{5}{c}{ Rabbit Temperature $\left({ }^{\circ} \mathbf{C}\right)$ Observed at Time- } \\
\cline { 3 - 8 } & & 30 & 60 & 90 & 120 & 150 & 180 \\
\hline I & 39.3 & 39.4 & 39.4 & 39.3 & 39.3 & 38.6 & 39.1 \\
II & 39.2 & 39.4 & 39.5 & 39.5 & 39.4 & 39.0 & 38.5 \\
III & 38.9 & 39.3 & 39.4 & 39.5 & 39.5 & 39.0 & 38.9 \\
\hline Total increase of temperature & 0.7 & 0.9 & 0.9 & 0.8 & -0.8 & -0.9 \\
\hline
\end{tabular}

the injection is not more than $1.5^{\circ} \mathrm{C}$; and the increase of temperature for each rabbits is below $0.6^{\circ} \mathrm{C}$. Therefore, this data indicates that this radiopharmaceutical was free from pyrogenic substances.

\section{CONCLUSION}

This study suggests that $99 \mathrm{mTc}-$ DTPA- Ketoconazole demonstrated negative toxicological effect to the animals in a single dose as well as acute toxicity test. The pyrogenic test also showed no negative response (increasing of temperature) due to the administration of radiopharmaceuticals. In addition, all the radiopharmaceutical kits are sterile as evidenced by the absence growth of the microorganism in the mediums. It can be concluded that 99mTc-DTPA-ketoconazole is a non-toxic radiopharmaceutical. It can be prepared as a sterile agent, and free of pyrogenic substances, and therefore appropriate for further biological analysis.

\section{REFERENCES}

Anonim. (2011). Tentang Antibiotik. 60 years Collaborating for a Healthy Indonesia. Retrieved May 18,2015, from http://www. ino.searo.who.int/linkfiles/home_whd 1 1-messages-11_03_31-faqs.pdf.

ANONYMOUS. (2008). Technical Reports Series No. 466, Eds, Tecnetium-99m Radiopharmaceuticals: Manufacture of Kits,, (). Vienna-Austria.

Awaludin, R. (2011). Radioisotop Teknesium99m dan Kegunaanya. Retrieved February
20, 2014, from http://www.infonuklir.com/ filedownload/Radioisot op dan Radiofarmaka untuk Berbagai Keperluan.pdf.

Dass, S. S., Hall, A. V., Wareham, D. W., Britton, K. E. (2002). Infection imaging with radiopharmaceuticals in the 21 th century,. Brazilian Archives of Biology.

Foxman, B. (2011). Infectious diseases. IARC Scientific Publications, (163), 421-440.

Halimah, I., Sumpena, Y., Sugiharti, R. J., \& Misyetti. (2009). Uji Toksisitas Akut Radiofarmaka 99mTc- CTMP Pada Mencit (Mus musculus). Prosiding Seminar Nasional Sains Dan Teknologi Nuklit, 347-351.

Hendris wongso, \& Halimah, I. (2013). Prinsip Uji Praklinis dan Klinis dalam Pengembangan Radiofarmaka Penyidik Kanker. In Seminar Nasional Viii Sdm Teknologi Nuklir (pp. 334-339). Yogyakarta.

Juwita, R., Kartini, N., Toksisitas, U. J. I., Pada, R. T., Mus, M., Test, T., Mice, T. I. N. (2007). Uji Toksisitas Radiofarmaka Tc-Etambutol Pada Mencit (Mus musculus), 17-18.

Kaul, A., Hazari, P. P., Rawat, H., Singh, B., Kalawat, T. C., Sharma, S., Mishra, A. K. (2013). International Journal of Infectious Diseases Preliminary evaluation of technetium99m-labeled ceftriaxone: infection imaging agent for the clinical diagnosis of orthopedic infection. International Journal of Infectious Diseases, 17(4), e263-e270. http://doi. org/10.1016/j.ijid.2012.10.011

Kementerian Kesehatan Republik Indonesia. (2014). Farmakope Indonesia (V). 
Jakarta: Dirjen Bina Kefarmasian dan Alat Kesehatan.

Maula Eka Sriyani, Desty Eltiana Ibrahim, Rizky Juwita S., A. H. W. (2015). Penentuan Uptake Candida Albicans terhadap Sebagai Kit Diagnostik Penyakit Infeksi Fungi. Prosiding Seminar Nasional Teknologi Energi Nuklir 2015.

Motaleb, M. A., El-Kolaly, M. T., Ibrahim, A. B., E.-B. A. A. (2011). Study on the preparation and biological evaluation of 99mTc-gatifloxacin and 99mTc-cefepime complexes. Hungaria: Akadēmiai Kiad.

Moustapha, M. E., \& Shweeta, H. A. (2016). Technetium- labeled danofloxacin complex as a model for infection imaging. Arabian Journal of Chemistry.

h t t p : // d o i org/ $10.1016 /$ j. arabjc.2014.10.017

Oh, K., Yamada, K., Asami, T., \& Yoshizawa, Y. (2012). Synthesis of novel brassinosteroid biosynthesis inhibitors based on the ketoconazole scaffold. Bioorganic and Medicinal Chemistry Letters, 22(4), 16251628.

http://doi.org/10.1016/j.bmcl.2011.12.120 Owunwanne A, Patel M, Sadek S. (1995). The Handbook of Radiopharmaceutical (1st ed.). London: Chapman \& Hall Medical.

Roberta, S., Rodrigues, C., Luís, A., Barros, B. De, Serakides, R., Odília, S., ... Andrade, R. De. (2015). Identi fi cation of Staphylococcus aureus infection by aptamers directly radiolabeled with technetium- $99 \mathrm{~m}$. Nuclear Medicine and Biology, 42(3), 292- 298.

h t t p : / / d o i.org/ $10.1016 / \mathrm{j}$. nucmedbio.2014.12.002 Saha, G. B. (2010). fundamentals of nuclear pharmacy (Sixth). Cleveland: Springer.

Schwochau, K. (2000). Technetium Chemistry and Radiopharmaceutical Aplications. Germany: Wi Ley-VCH.
Sriyani, M. E., Ibrahim, S., \& Hanafiah, a. (2013). Optimalisasi Penandaan 99mtcDtpa- Ketokonazol Sebagai Radiofarmaka Untuk Deteksi Infeksi Fungi. Jurnal Penelitian, 04, 11-22.

Sriyani, M. E., \& Ws, A. H. (n.d.). Physicochemical Characteristic of $99 \mathrm{~m}$ Tc-DTPA-ketoconazole as a Radiopharmaceutical for Deep Seated Fungal Detection ISBN : 978-979-965954-5 ISBN : 978-979-96595-4-5, (71), 978-979.

Tjay, T. H., \& Rahardja, K. (2007). Obat-obat Penting. Khasiat, Penggunaan dan Efekefek Sampingnya (6th ed.). Jakarta: PT. Elex Media Komputindo.

Verbruggen, A M. (2007). Technetium-99m Radiopharmaceuticals Current Situation and Perspectives. Belgia: Laboratory of Radiopharmacy, Katholieke Universiteit Leuven.

Welling, M., Ferro-Flores, G., \& Pirmettis, I. (2009). Technetium-99m Labelled Infection Imaging Agents. Technetium99m Radiopharmaceuticals: Status and Trends, (1), 137-156. Retrieved from http:// www- pub.iaea.org/MTCD/publications/ PDF/Pub1405_w eb.pdf

Yazdani, A., Pitchunmony, T. S., Banevicius, L., Czorny, S., \& Valliant, J. F. (2014). Characterization of $99 \mathrm{mTc}$-caspofungin as fungal infection agent and assessment of potential influence of pretreatment. Nuclear Medicine and Biology, 41(7), 616. http://doi. org/10.1016/j.nucmedbio.2014.05.093

Z, Nurlaila., Basry, H. T., Iljas, R., Suminar, R, M. (2005). Karakterisasi radiofarmaka 99mTc-siprofloksasin sebagai penyidik infeksi. Majalah Farmasi Indonesia, 16(4), 217.

Zolle, I. (2007). Technetium-99m Pharmaceuticals. New York: Springer. 